\title{
Pro bono and Young Solicitors: Views from the Front Line.*
}

\author{
LISA WEBLEY ${ }^{1}$
}

\section{Introduction: Pro bono and Young Solicitors}

The value of pro bono publico services provided by the legal profession in the United Kingdom has continued to attract attention. Academic interest has focused upon the ethical context of pro bono work and the interplay between social and professional motivations behind the resurgence of interest in it. ${ }^{2}$ One of the reasons sometimes advanced is the inherent altruism of the young. It has, however, been argued that altruism is insufficient unless there is organisational firm-based support for pro bono publico. ${ }^{3}$ Further it has been suggested that other pressures, for example commercial pressure on large law firms, are more significant to pro bono uptake by young solicitors. $^{4}$ This article outlines the results of quantitative research into the legal services provided pro bono publico by young and trainee solicitors or pro bono according to the definitions advanced by young solicitors themselves. It considers issues of definition, performance and motivation across a range of solicitors firms, from legal aid to large commercial practices. Finally, it addresses the issue of what motivates young lawyers to provide free services and what steps might be taken to increase participation.

\footnotetext{
* I am most grateful to the Trainee Solicitors Group and Young Solicitors Group of the Law Society of England and Wales for commissioning this research and for providing enthusiastic support throughout the survey. My thanks also to Andy Boon for his most helpful comments on an earlier draft of the article. The views expressed are of course my own, as are any errors.

${ }^{1}$ Senior Lecturer in Law, University of Westminster and Research Fellow, Institute of Advanced Legal Studies, University of London, UK.

${ }^{2}$ See for example A. Boon and J. Levin The Ethics and Conduct of Lawyers in England and Wales (Oxford, Portland Oregon, Hart Publishing 1999), D. Nicolson and J. Webb Professional Legal Ethics: Critical Interrogations (London \& New York, Oxford University Press, 1999), A. Boon and A. Whyte "Charity Begins at Home: The Aetiology of the New Culture of Pro bono Publico [1999] LE 169, on the ethical dimension to pro bono, also M. Galanter and D. Palay "Large Law Firms and Professional Responsibility” in R. Cranston (ed.) Legal Ethics and Professional Responsibility (Oxford, Clarendon Press, 1995) at 201 and R. Abbey and A. Boon "Moral Agendas: Pro bono Publico in Large Law Firms in the UK” (1997) 60 MLR 630 for an insight into the increasing interest by large law firms in pro bono work between 1990 and 1994.

${ }^{3}$ See Boon and Whyte ibid. p. 174.

${ }^{4}$ The resurgence in pro bono may, however, be short-lived if trends in the USA are followed in Britain. In a survey carried out by American Lawyer magazine in July 2000, it was reported that of the 50,000 lawyers in the highest grossing American law firms have cut their pro bono hours from an average of 56 hours per year in 1992 to 36 hours per year in 1999 (as reported in the New York Times, August $17^{\text {th }} 2000$ by Greg Winter and circulated by the Brennan Center Legal Services Alert). It was suggested that these firms had to concentrate on fee-earning in order to meet the high salaries that their solicitors are now commanding. As City law firms seek to compete for staff with American firms in London this too may affect pro bono schemes within these firms also.
} 


\section{Research Methodology}

Against the backdrop of calls for increased pro bono publico, the Trainee Solicitors Group and the Young Solicitors Group of the Law Society funded research to investigate current attitudes towards pro bono, the nature and extent of participation and, in addition, the perceptions of law firms towards participation by young professionals.

The survey was undertaken by questionnaire in the autumn of $1998 .{ }^{5}$ Questionnaires were sent to a randomly selected group from the total population of young solicitors and trainees, the sample stratified by geographical area and gender. Two hundred and twenty-two questionnaires were returned (217 valid responses) out of a total sample of 1,000: 500 trainees and 500 young solicitors. It is considered that the respondents are as representative of the young profession as any questionnaire survey can hope to be within the limits of a self-selecting group of this type.

The survey provided some insights into how trainee and young solicitors (hereafter "the young profession" or "young solicitors") view pro bono work and the remainder of this article sets out the research findings.

\section{Views from the Front Line}

\section{a) A question of definitions}

The definition of pro bono work in recent times has itself remained illusive. ${ }^{6}$ This survey sought to clarify what the young solicitors' profession subjectively considered pro bono work to be, in part as a means of setting parameters for measuring participation and, at another level, to act as an indicator of views on the provenance of pro bono.

Respondents to the survey mirrored the definitional difficulties experienced by more senior members of the profession and others, ${ }^{7}$ adopting very wide definitions of "pro

\footnotetext{
${ }^{5}$ The survey was sponsored by five City law firms: Allen and Overy, Clifford Chance, Herbert Smith, Linklaters and Paines and Lovell White Durrant.

${ }^{6}$ Boon and Whyte found that practitioners thought pro bono work ranged from legal services provided entirely free of charge or at a significantly reduced cost, non-legal work and support for community projects in money or money's worth, see supra n.2 at pp. 176-180. For an illustration of the debate see Solicitors Serving Society: A Report of the Pro bono Working Party (London: Law Society, 1994) and Abbey and Boon also supra n.2.

${ }^{7}$ The Law Society's Pro Bono Working Party suggested a wider definition which encompassed public service: See Solicitors Serving Society: A Report of the Pro Bono Working Party (London; Law Society, 1994). The Law Firm Pro bono Projects' definition was even broader including work such as "serving as general counsel to community organizations, involvement in community economic development work, creating venture capital for low-income individuals and businesses, developing affordable housing and many other skills critically needed by poor and disadvantaged individuals and their communities". See The Law Firm Pro bono Project Summary p. 4 (Washington D.C.: The Pro bono Institute, 1999). The Law Council of Australia's definition as adapted by Voluntas of the Victoria Law Foundation is narrower in scope and focuses more on the process of lawyering and legal education. The full definition is available at the Victoria Law Foundation's website: http://www.viclf.assn.au/vol.what.htm.
} 
bono". ${ }^{8}$ Respondents were asked to select examples from a list and to add examples in an "other" category. The categories provided and findings were as follows: thirty-one percent $(n=67)$ indicated that advice given outside the office on external sites could fairly be defined as pro bono work. For a substantial proportion it included the provision of free first interviews (twenty-seven percent, $n=59$ ), although this could lead on to full fee-paying work. Significantly, however, by far the majority of young professionals considered charitable work (sixty-five percent, $n=142$ ) to fall squarely within the definition even though this could cover non-legal activity including fundraising for a local charity or organisation. This points to charitable intentions and possibly public service but not to a professional ethic linked to the practice of law, the privilege it brings and the responsibilities that are associated with that unique position. ${ }^{9}$

Trainees and young solicitors had similar outlooks, with two exceptions. Qualified solicitors adopted a much wider approach to pro bono: charitable work was accepted as pro bono by marginally more qualified solicitors ${ }^{10}$ and they were also significantly more accepting of "other" activities within the definitions of pro bono work. ${ }^{11}$ Attitudes differed more markedly between male and female respondents. Men were significantly more likely than women to consider "other" activities within the heading of pro bono services ${ }^{12}$ and were less inclined than women to consider many of the listed activities as pro bono legal work. Generally women were less concerned with the venue or the framework within which pro bono work was carried out, however, they were also more sceptical about whether the clients benefited from its provision and firms' motivations in providing pro bono services. They appeared to be less interested in where the service was provided but more concerned about the nature of the service and how it benefited clients.

Lawyers from different types of firms displayed different attitudes, although the numbers within categories of firm were small and generalisations are tentative. Legal aid solicitors were less likely than the other types of firm to accept the questionnaire's defined activities as pro bono work, and instead provided diverse examples of other forms of work including finishing legal aid cases for free when funding had run out or providing representation outside the scheme (seventy percent, $n=9$ ). High street practices and in-house lawyers appeared more likely to regard first interview free schemes and law clinics as pro bono legal work, whereas commercial lawyers were more inclined to define charitable work and advice given on external sites as pro bono work. These predispositions were consistent with their own pro bono methods of delivery. Smaller firms are more likely to serve clients who would be in need of free first interviews and, by contrast, larger firms may serve clients at external venues, as

\footnotetext{
${ }^{8}$ Respondents could choose any or all of the following: advice on sites external to the office, first hour interview free, law clinics within the firm, charitable work or they could specify another activity.

${ }^{9}$ For a discussion of professionalism see E. Friedson, Professionalism Reborn. Theory, Prophecy and Policy (Oxford, Polity Press 1994) pp. 13-29. For a discussion of the legal profession and ethics see D. Luban, Lawyers and Justice: An Ethical Study (Princeton, NJ, Princeton University Press, 1988).

${ }^{10} 70 \%$ noted this option as opposed to $62 \%$ of trainees.

${ }^{11}$ Pearson's chi-square test, used throughout to test relationships between variables. $56 \%$ vs. $42 \%$, $\chi^{2}=4.404, \mathrm{p}=0.036$.

${ }_{12}$ Women were significantly more likely to consider law clinics held within the firm as pro bono work: $43 \%$ vs. $26 \% \chi^{2}=6.463, \mathrm{p}=0.011$. Men were significantly more likely than women to consider "other" activities within the heading of pro bono services: $56 \%$ vs. $42 \% \chi^{2}=4.404, p=0.036$.
} 
the clients who visit them at their offices are traditionally drawn from an affluent business setting and who are not in need of pro bono services.

Therefore, when young and trainee solicitors consider pro bono they too experience the definitional difficulties that have dogged the pro bono debate to-date. Their views appear to be shaped by gender and the type of firm for whom they work, although there is evidence to suggest that they tend to adopt broader rather than narrower definitions with experience. Forces other than experience also appear to play a role in developing their views, as illustrated by the changing patterns of pro bono participation and views on how their firms react to it, as discussed below.

\section{b) Levels of Pro bono Participation}

Little systematic data has been available within the UK on individual or firm involvement in pro bono. The Law Society released figures to indicate the amount of lawyer time spent on pro bono ${ }^{13}$ and individual firms have publicised the financial value of their pro bono cases ${ }^{14}$, however, these have done little more than provide guidance, if that, on true levels of pro bono participation. Participation in pro bono within this sample of the young profession was high at thirty-eight percent $(n=83)$, although admittedly this figure in itself does not reveal the extent of that participation. ${ }^{15}$ Just under a quarter of first year trainees carried out pro bono work, the lowest figure across the sample (twenty-four percent, $n=8$ ), second year trainees carried out substantially more at thirty-nine percent $(n=35)$. The main pro bono workers were those solicitors who were one to two years qualified (forty-nine percent, $n=22$ ), with participation dropping off slightly for solicitors who were between three to five years qualified (forty percent, $n=18$ ). If this finding were to hold across the population of young solicitors, the view expressed by some anecdotally during the survey, that pro bono work, whilst being advocated by more senior members of law firms was being carried out by the junior profession, would be supported. It also begs a number of questions relating to the experience level of those members of the profession who carry out free or reduced cost legal services and the extent to which they are qualified and/or supervised to carry out the work they are undertaking.

Participation was not uniform across all types of firm either, although again this should be balanced against the small sample sizes within some categories of firm. Legal aid lawyers were more likely to say that they carried out pro bono work (ninety-two percent, $n=12$ ), although high street practice solicitors and trainees also indicated that they carried out substantial amounts (fifty-seven percent, $n=25$ ). A similar level of participation was found for those solicitors and trainees who classed themselves as

\footnotetext{
13 J. Jenkins, Law Society Omnibus Survey 2: Report 5: Pro bono Activities Conducted by Private Practice Solicitors (London: The Law Society, 1997).

${ }^{14}$ The solicitors and barristers acting for pensioners bringing an action against the National Grid were reported in the Guardian to have given $£ 200,000$ free advice and representation. "'Mean' Lawyers Not Guilty" The Guardian 6 ${ }^{\text {th }}$ April 1999. See also Boon \& Abbey "Moral Agendas: Pro bono Publico in Large Law Firms in the UK” 60 Modern Law Review 630.

15 The survey indicated that $38 \%$ of respondents $(n=83)$ claimed to carry out pro bono work, $60 \%$ $(n=130)$ expressly stated that they did no pro bono work and $2 \%(n=4)$ did not indicate either stance. Direct comparisons with other jurisdictions are difficult to make due to different professional policies on pro bono and also different recording mechanisms.
} 
working for "other" types of practice. Part of the reason for such high levels of pro bono work amongst these groups may be explained by respondents' wide definitions of pro bono work, and may include some work that is part of their daily working life.

More surprising, perhaps, is that over a third of City commercial practitioners claimed to carry out some pro bono work, as did one in five non-London commercial practice solicitors. Pro bono work was not carried out by local government lawyers and this very small group within the survey suggested that they did not feel that they were permitted to do so as it may lead to later conflicts of interest in their role as local government lawyers. ${ }^{16}$ It is unlikely that pro bono work in the sense described by legal aid and high street firms (for example finishing off cases when legal aid work has run out or taking on cases when clients could not afford to instruct a solicitor) could be responsible for the levels of participation described within commercial practice. Such opportunities would not be present within the normal working day. This suggests that pro bono not only covers many forms of fee arrangements but also embodies diverse legal activities and subject areas. This is discussed below.

\section{c) Reasons For and Against Undertaking Pro bono}

There appeared to be a twin motivation expressed by members of the young profession, namely that they felt they ought to contribute their services for free to some clients and also that they could further their own careers in the process with support from their firms. Over half of the respondents when asked their reasons for undertaking pro bono stated that they did so due to a commitment to the community (fifty-three percent, $\mathrm{n}=44$ ), for client contact reasons (fifty-seven percent, $n=47$ ), and for personal development (forty-eight percent, $n=40$ ). Firms did wield some power over the young profession in that just under half of respondents were instructed to carry out pro bono work by their firm (forty-seven percent, $n=39$ ). ${ }^{17}$ One respondent commented that:

" [Pro bono is] something different from work; [I am] able to develop new skills. The pro bono work I do is actually in my home borough and luckily my firm felt able to support the activity and encourages others in the office to do the same."

Certainly for this respondent, staff development appeared to be an important issue, the implication being that the firm was willing to support participation on that basis too. ${ }^{18}$ In addition it is clear that a substantial proportion of young solicitors were asked to do pro bono work by their firm rather than doing it of their own volition. There is,

\footnotetext{
${ }^{16}$ On the $29^{\text {th }}$ April 1999 Lord Phillips of Sudbury asked Her Majesty's Government "whether they will give legal staff in government service the opportunity to undertake pro bono work during the course of their employment ..." Hansard HL 2026 Written Answers. The Lord Chancellor replied that he encouraged "any member of the Government Legal Service who wishes to participate in pro bono work in their own time, to do so". However, he noted that lawyers would also be bound by the Civil Service Code and the Civil Service Management Code whilst undertaking this work as they were public servants employed to advise the government.

17 Respondents could choose any number of reasons from the following options: commitment to the community; client contact; personal development; instructed to do so by their firm; “other”. 27\% gave other reasons. The four most frequently expressed were: commitment to the firm $(n=5)$; able to develop new skills $(n=2)$; as a perk for important or existing clients $(n=2)$; make up the difference where legal aid won't cover the full costs of the case, but it is necessary to do more work to safeguard the client's interests $(\mathrm{n}=2)$.

${ }^{18}$ Although it was unclear from the response whether there was an advertising gain for the firm, the full text of the comment suggested that this was not the case.
} 
however, also some cynicism expressed by respondents as to firms' motivation for asking. ${ }^{19}$

Trainees and young solicitors gave different reasons for their decision to carry out pro bono legal work. Qualified solicitors were more likely to do so as a commitment to the community, whereas trainees gave the reason of personal development most often, and significantly more frequently than qualified solicitors within the sample. ${ }^{20}$ This division, between personal development and commitment to the community, may reflect confidence about their ability to provide a service to the community rather than a true shift in motivation to carry out pro bono. Firms were also more likely to instruct their trainees to carry out pro bono (fifty-four percent, $n=23$ of trainees) than their qualified young solicitors (forty percent, $\mathrm{n}=16$ of qualified solicitors), also strengthening the claim that pro bono is a good mechanism for gaining valuable client experience.

Men and women appeared equally likely to express a commitment to the community as a motivating factor for carrying out pro bono work. More women expressed increased client contact as an allied reason, whereas men were greatly and statistically significantly more motivated instead by personal development (sixty-two percent, $n=20$ vs. forty percent, $n=20$ of women).$^{21}$ Women, on the other hand, were more likely than men to be instructed to carry out pro bono by their firm (fifty-one percent, n=27 vs. forty-four percent, $n=15$ ). This may reflect the slightly higher participation figure for women, or a culture within firms which makes it more likely that it will be women who carry out unpaid work whilst male staff concentrate on fee-paying work. It is unclear from the data whether there is a true difference in male and female work patterns, attitudes to work, or feelings about the merits of pro bono participation. Anecdotal evidence from this survey suggested that young female solicitors would prefer greater client contact and pro bono might be the vehicle for them to achieve this.

Distinct cultures between different types of law firm were evident in the responses. Legal aid practitioners were most likely to state that they undertook pro bono work through a commitment to the community (sixty-seven percent, $\mathrm{n}=8$ ). City commercial practitioners favoured personal development reasons (seventy percent, $n=19$ ), whereas client contact reasons were high for non-London commercial solicitors (eighty-three percent, $n=5$ ) even though they, along with high street solicitors, felt under the most time pressure. Once again views appeared to be coloured by environment.

Few respondents who undertook no pro bono work said that they were not interested in it, $^{22}$ nor that they were discouraged from doing so by their firm. ${ }^{23}$ This was not true across the board as different types of firm appeared to adopt particular positions on pro

\footnotetext{
${ }^{19}$ See the section below on Individuals' Attitudes to Pro bono Work for further detail.

${ }^{20} 63 \%$ vs. $33 \%, \chi^{2}=7.615, p=0.006$.

${ }^{21} \chi^{2}=4.270, \mathrm{p}=0.039$.

22 They could choose any number of reasons from a list of options: not interested; discouraged from doing so by the firm; do not know how to proceed, never considered it, do not have the time, other reason. Only eleven percent $(n=14)$ were not interested in carrying out pro bono. The gender divide was stark: only three percent $(n=2)$ of women who did not pro bono claimed that they had no interest in doing so as opposed to twenty-one percent $(n=12)$ of men.

${ }^{23}$ Nine other reasons for not undertaking pro bono work were voiced on more than one occasion, the most frequent being: No opportunity to do so at my present firm/ no firm policy ( $n=13)$, Specialise in an area of work that does not lend itself to pro bono clients i.e. corporate or residential conveyancing $(n=6)$.
} 
bono. High street practitioners were more likely to receive a strong signal from their firm, either by being encouraged to carry out pro bono legal services (fifty-six percent, $n=14$ ) or discouraged from doing so (thirty percent, $n=6$ ). West London and nonLondon commercial firms also discouraged pro bono activity, but to a far lesser extent (twenty-two percent, $\mathrm{n}=2$ and nineteen percent, $\mathrm{n}=5$ respectively). A substantial group did not know enough about pro bono in order to participate ${ }^{24}$ and the lack of knowledge was not limited to trainees. ${ }^{25}$ As one respondent wrote:

"Before reading John Grisham's book "The Street Lawyer" [I] didn't know anything about pro bono work."

A small number were concerned that they may not have the necessary skills or expertise to carry out pro bono work effectively:

"I am not aware of any pro bono work being done by this firm ... and time and lack of experience would preclude me doing anything independently."

The majority, however, did not provide pro bono services as they felt that they did not have the time to do so (fifty percent, $n=65$ ). In particular the regular time commitment that was required to participate in pro bono schemes outside of the firm posed difficulties:

"I did volunteer to work at a local law centre but it was difficult to set up and then commit myself to spending that much time regularly so I did not proceed with the idea."

Lack of time was the most frequent answer for City solicitors, pointing to the feeling within the young profession that they are already overburdened with work. ${ }^{26}$ Trainees in this survey were less, but not significantly less, likely to feel under time pressure and women were significantly more likely to say that they did not have the time to work pro bono. $^{27}$

If lack of time is such a major inhibitor of pro bono then initiatives to promote pro bono work will have to come from the firms themselves, through a commitment to accommodate it within the existing working day, rather than in addition to current case loads. It does not appear to be enough for firms to express their principled commitment to pro bono, active support may be necessary as well if participation is to increase.

\section{d) Participation: When, Where and How?}

\footnotetext{
${ }^{24}$ Just over a third did not know how to proceed with their wish to do pro bono (thirty-five percent, $n=45)$, and twenty-one percent $(n=28)$ had never even considered it. The United States experience shows that there has been an increase in the number of law firms with formal written pro bono policies (three quarters of large law firms according to their survey) and that this may have gone some way to raising awareness of pro bono within firms. The Law Firm Pro bono Guide- The Law Firm Pro bono Project, (Washington D.C.: The Pro bono Institute 1999) at 1.

${ }^{25}$ Commercial practitioners outside London did not know how to go about providing pro bono services and were under time pressure. In-house lawyers and West End commercial solicitors require further guidance. In particular in-house lawyers were unsure whether they are permitted by their employer and the Law Society to carry out pro bono and whether their professional indemnity insurance covers their practice in this respect.

${ }^{26}$ See R. Moorhead, Stress: A Business Case for Quality of Life in the Legal Profession. (London: Young Solicitors Group 1998) for more information on stress factors in the young profession.

${ }^{27} 58 \%$ vs. $40 \%$ of men, $\chi^{2}=3.780$, $p=0.038$
} 
Little is known about the profile of pro bono work undertaken by the young profession, whether it is carried out in office hours or exclusively in their own time, what venues are used, whether supervision is given and what types of legal problem are covered and by whom. Solicitors were therefore asked to give details about their pro bono participation: when they carried out pro bono work, how and where. They were asked to classify their pro bono activity into work in office hours, work outside office hours, or work carried out both within and outside the working day. They were then asked how much time a month they spent on pro bono activities and whether they received supervision for this work. Finally they were asked to state where they carried out this work. ${ }^{28}$

Work was predominantly undertaken both inside and outside office hours (fifty-two percent, $n=45$ ), or within office hours only (thirty-eight percent, $n=33$ ), rather than solely outside work hours (ten percent $n=9$ ). Qualified solicitors were more likely to spend both time within and outside work carrying out pro bono work, rather than trainees (fifty-six percent, $n=23$ vs. forty-eight percent, $n=22$ ). Men also appeared to be more likely to carry out pro bono work both during and outside working hours (seventyseven percent, $n=26$ vs. thirty-six percent, $n=19$ ), whereas women appeared to be more likely to carry out pro bono in working hours (fifty-five percent, $\mathrm{n}=29$ vs. twelve percent, $n=4$ ). The vast majority of this pro bono was carried out in the office (eightythree percent, $n=73$ ), although substantial amounts were also carried out at CABx or other advice centres (twenty-one percent, $\mathrm{n}=18$ ) and at law centres (seventeen percent, $\mathrm{n}=15) .{ }^{29}$ The predominance of office-based pro bono work indicates that firms accept pro bono participation by their staff and to a certain extent, whether passively or actively, support it. ${ }^{30}$

While pro bono levels appeared to be high, the actual time spent on pro bono work was, however, limited. Twenty-seven percent $(n=22)$ of the pro bono active profession carried out less than 2 hours' pro bono work a month. Forty-six percent $(n=37)$ spent between 2 and 5 hours a month on pro bono work, sixteen percent $(n=13)$ spent between 5 and 10 hours a month and ten percent $(n=8)$ spent more than ten hours a month on pro bono activities. Few qualified solicitors spent more than 5 hours a month providing free or reduced price legal service to clients, as compared with a third of trainees. Although there were no statistically significant differences between the time spent by men and women on pro bono work, there were some differences in participation periods. Women and men spent similar proportions of time at the low end of the spectrum, although once they provided more than 5 hours a month, women gave more time than male respondents did. ${ }^{31}$ This may again reflect the fact that firms appeared to actively

\footnotetext{
${ }^{28}$ Respondents could choose any number of the following: in the office; at a law centre; at a CAB or other advice agency; as part of a law courts duty scheme; "other".

${ }^{29}$ Pro bono work is also carried out in schools $(n=2)$, at the clients' own premises $(n=1)$, at solicitors' homes $(n=3)$, magistrates courts $(n=1)$, universities $(n=1)$, charitable organisations $(n=2)$, local shopping centres $(\mathrm{n}=1)$, in the community $(\mathrm{n}=1)$ and through help-lines $(\mathrm{n}=2)$.

${ }^{30}$ Much of the work is also supervised, suggesting a degree of support from colleagues in the firm (62\% supervised).

${ }^{31} 32 \%(n=15)$ of women who answered the question spent 5 hours or more per month on pro bono compared with $19 \%(\mathrm{n}=6)$ of men. Twice as many women as men spent more than 10 hours a month on pro bono work (twelve percent, $n=6$ vs. six percent $n=2$ ). The sample sizes are, however, small and should be considered as illustrative of difference rather than proof of it.
} 
encourage women to carry out work pro bono and also that women were more likely to carry this work out in the office rather than at external venues.

The young profession tended to be supervised for its pro bono work. Trainees, understandably, were significantly more likely to receive supervision in their pro bono activities than qualified solicitors (eighty percent, $n=31$ vs. forty-three percent, $n=15$ ). ${ }^{32}$ The survey does not record their attitudes towards the level and quality of the supervision that they receive, so few conclusions may be drawn on this point. It is notable that twenty percent of trainees were left entirely unsupervised in their pro bono activities. This may be because their pro bono work is carried out away from the office or without the support of a member of their firm, although there is no statistically significant relationship between supervision and pro bono work carried out in the office. Much pro bono was, however, firm based suggesting that supervision was available from other staff within the firm, as it is unlikely that firm-based pro bono would be supervised by an external legal adviser. This too adds weight to the contention by many firms that they do actively support pro bono work and provide support for their junior staff who undertake it.

\section{e) Areas of Pro bono Work}

Pro bono work spanned a wide variety of legal subject areas, although over half of all those who carried out pro bono work undertook some debt work ${ }^{33}$ (fifty-two percent, $n=46$ ). Employment (forty-seven percent, $n=41$ ), housing (forty-six percent, $n=40$ ) and welfare benefits (forty-two percent, $n=37$ ) were also carried out by a large number of solicitors. ${ }^{34}$ One would expect social welfare areas of law to receive a lot of attention within a pro bono environment, although it is interesting to note that many of these clients would also be eligible for legal aid assistance, particularly in relation to welfare benefits work. $^{35}$ No subject areas were unrepresented within the sample, although very little immigration or charity work was carried out. ${ }^{36}$ Company and commercial work too featured alongside the more traditional social welfare areas of law at nineteen percent of all responses, even though it would be unusual to consider commercial work for a company, as opposed to an individual, as pro bono assistance in the strictest sense. $^{37}$ It could be suggested that, whilst company/commercial and property law were

\footnotetext{
${ }^{32} \chi^{2}=10.862, \mathrm{p}=0.004$.

33 This was not broken down by debt advice or debt collection and, therefore, could cover very different types of work.

${ }^{34}$ The College of Law's free advice centre reported that the bulk of its cases, during the first 6 months of providing the service, were consumer issues $(n=16)$, property disputes $(n=9)$ and employment problems $(n=5)$, rather than the high levels of debt, welfare and housing work provided by the young profession on this survey's figures. See Grania Langdon-Down, “Apprentices Take up the Case” The Times July $11^{\text {th }}$ 2000.

${ }^{35}$ The survey did not reveal whether the pro bono service offered to clients is complimentary to any legal advice and assistance to which they may be entitled (for example free representation at tribunals for which legal aid will not be given) or whether clients were accessing pro bono services in preference to or in the absence of legal aid services.

36 The list of subject areas stated in the questionnaire was: benefits/welfare, charity, company/commercial, criminal, debt, employment, family, housing, immigration, other, personal injury, property.

${ }^{37}$ Having said that, the American Bar Association does run a pro bono business law service for clients who otherwise would not be able to afford legal assistance, suggesting that there must be a need for such work. This resource is aimed at people and organisations of limited means, individuals who wish to
} 
among the list of pro bono activities, and particularly so for men from commercial practices, the motivation for carrying out pro bono work in these areas was less likely to be an ethical obligation to provide access to justice for those on low incomes, but rather to assist existing clients or potential clients, or to further career development.

Solicitors from commercial firms, aside from commercial law areas, nonetheless carried out a high level of social welfare law, even though it is not their normal area of practice. This was especially true for women, whilst men tended to carry out a mix of social welfare and commercial subjects. A concern expressed by one respondent is of particular relevance here and relates to the qualification or level of knowledge that some solicitors may have in the areas of law on which they provide pro bono advice. ${ }^{38}$ It is intrinsic to the principle of access to justice that all clients receive accurate and timely advice, regardless of how those services are funded. To do otherwise promotes a twotier system based on the client's ability to pay. It may be difficult for solicitors to provide a good quality of service to clients if it is outside their normal and current areas of expertise and if they have not received training on the area. This is as true for those who supervise pro bono work as for those carrying out the work, if they do not have upto-date knowledge of the law in those areas.

\section{f) Firms' Attitudes to Pro bono Work}

Firms' organisational approaches to pro bono participation by their staff were diverse although there was some connection between organisational approaches and the size of the firm. In overall terms forty-one percent $(n=37)$ of responding solicitors felt that their firm left the decision as to whether to participate in pro bono work up to them. ${ }^{39}$ A further thirty percent $(n=27)$ were actively encouraged to carry out pro bono by their partnership, although very few (two percent, $n=2$ ) stated that it was mandatory for them to carry out some pro bono. Fourteen percent $(n=13)$ required their staff to obtain partner approval before commencing pro bono and a further thirteen percent $(n=12)$ were actively discouraged by their firm from undertaking free or reduced cost work.

More qualified solicitors felt that they were allowed to take their own position on involvement (fifty-three percent, $n=20$ vs. thirty-two percent, $n=17$ ), whereas trainees felt more frequently encouraged to do pro bono, explained by one trainee as the firm's wish that they widen their experience at an early stage in their careers (thirty-four percent, $n=18$ vs. twenty-four percent, $n=9$ ). Interestingly, trainees also felt more discouraged from undertaking pro bono than young solicitors did. It appears that some firms seek to regulate their trainees' participation more than they do for qualified staff, or alternatively that their trainees perceive that there is greater regulation. Firms'

establish non-profit making organisations to help this group of people and who can't afford fees, and for charitable, religious, civic, community, governmental and educational organisations who would have their economic resources significantly reduced if they were required to pay legal fees. A Business Commitment (AB) Project, summary to be found at the ABA's website at http://www,abanet.org/buslaw/probono/abcprogram.html

${ }^{38}$ This concern has been expressed elsewhere. See for example Counting the Cost of Conscience The Guardian January $23^{\text {rd }} 1999$.

39 Respondents were asked to choose the option which best described their firm's attitude from the following list: decision is left to individual's own choice; partner approval is required; pro bono work is actively encouraged by the partnership; it is mandatory to undertake some pro bono work; the firm discourages pro bono work. 
approaches did, however, follow patterns of supervision in that those firms that actively encouraged pro bono work also provided supervisory support, whereas those that left the decision to individuals were less likely to provide back up for their staff.

The gender difference was apparent, if not statistically significant, once again in relation to firms' attitudes towards pro bono work. It is not possible from this study to unbundle whether this reflects gendered perception on the part of the respondents, or on the part of the firm. It is, however, interesting to note that women were less likely to report that their firm discouraged them from carrying out pro bono (nine percent, $n=5$ vs. eighteen percent, $n=7$ ) and they were also less likely to have felt that the decision was left up to them (thirty-eight percent, $n=20$ vs. forty-five percent, $n=17$ ), because they were either required to undertake some pro bono work, or to seek partner approval before they did so. This fits in with other findings within the survey revealing that the women who carried out pro bono were more likely to be instructed to undertake pro bono work than were the men. This may also explain women's higher levels of participation in pro bono work. ${ }^{40}$

Firms' attitudes towards pro bono work, as judged by the respondents in this sample, did appear to reflect their size and area of work. Smaller firms appeared more likely to have a strict policy on staff pro bono participation when compared with their larger counterparts, although the use of definitive pro bono participation policies peaked with medium sized firms of between 21 and 50 fee-earners at sixty-two percent $(n=8)$. Partner approval was also required in small to medium sized firms and the extremely large ones. City practices were the most likely to actively encourage their staff to participate in pro bono work. ${ }^{41}$ Legal aid firms were most likely to leave participation up to the solicitor to decide, whereas high street firms had diverse policies, ranging from discouragement to mandatory participation. Smaller to medium sized firms were the only ones within the sample who actively discouraged pro bono work, again in particular the smallest firms. This may relate to their ability to allow staff the time to do this within working hours, their cash flow situation or that more senior staff were unavailable or unwilling to supervise the pro bono work for junior staff. Firms' organisational responses appeared to colour their solicitors views on pro bono and had a direct, although admittedly unquantifiable impact, on their rates of participation in pro bono services.

g) Individual's Attitudes towards Pro bono Work: Professional Ethical Responsibility or Professional Necessity?

The questionnaire proved to be particularly revealing of respondents' feelings on the relationship between pro bono work and law firms, about their own ideology of pro bono work and also about their experience of the pro bono work they undertook or would like to carry out. ${ }^{42}$

\section{i. Individual's Ideology of Pro bono Work}

\footnotetext{
40 Once again these differences are subject to the caveat that they are based on small sample sizes.

${ }^{41}$ This was also found to be the case in research conducted in the USA by Galanter and Palay, see surpa n. 2 at p. 46.

42 The young profession was asked to classify its attitudes on a scale of 1 to 5 - ranging from strong agreement at 1 to strong disagreement at 5 .
} 
The questionnaire posed two hypotheses to test individual's ideologies of pro bono work to understand the context within which young solicitors do or do not decide to undertake pro bono work. The two hypotheses were:

- An undertaking to do pro bono work is part of a solicitor's professional and ethical obligations.

- A commitment by the profession to pro bono work would improve the public image of the profession.

Two thirds (sixty-six percent, $n=130$ ) of young solicitors did not disagree with the proposition that undertaking pro bono is part of a solicitor's professional and ethical obligations, although only forty-four percent $(n=86)$ actively agreed. This was equally true for both men and women, however, this feeling appeared to be heavily influenced by the type of firm from which respondents came. City commercial firms were least likely to agree that pro bono was a professional and ethical duty (forty-two percent, $\mathrm{n}=31$ disagreed and only thirty-eight percent, $\mathrm{n}=28$ actively agreed), legal aid practitioners and in-house solicitors were most likely to agree (sixty-nine percent, $n=9$ and seventy-one percent, $n=5$ actively agreed). Trainees were more likely to consider pro bono a duty rather than their qualified counterparts (fifty-nine percent, $\mathrm{n}=61 \mathrm{vs}$. thirty-six percent, $n=33$ ) who were more likely to strongly disagree that it was (eighteen percent, $n=16$ as opposed to five percent of trainees, $n=6$ ).

A large majority of solicitors felt that a commitment to pro bono work would improve the public image of the profession (eighty-eight percent, $n=189$ ). Forty-one percent $(n=88)$ strongly agreed with this statement and a further forty-seven percent $(n=101)$ agreed. $^{43}$ Qualified solicitors were more ambivalent than trainees about the effect of pro bono on the profession's image (thirteen percent, $\mathrm{n}=12$ as opposed to four percent, $\mathrm{n}=5$ ). Consequently, some respondents felt that pro bono was not part of a solicitor's professional responsibility, but did feel that the image of the profession could be improved and that pro bono work is a vehicle for doing so. Whether this is political expediency, a realistic understanding of the nature of good publicity or a genuine belief in the value of pro bono removed from any ethical obligation, is unclear. It does however highlight the fact that many within the young solicitor's profession appreciate that the public views pro bono as a positive contribution to society by the profession.

\section{ii. Provision of Pro bono Work by Firms}

The questionnaire asked respondents to rate their attitude in respect of four statements:

- Pro bono clients are not given as good a service as other clients of the firm.

- The pro bono work the firm does is often extra work provided for existing clients.

- The pro bono work that my firm does is mainly used as a public relations exercise.

- The pro bono work that my firm does provides a valuable service to the community.

A small majority of young solicitors felt that pro bono clients were given as good a service as other clients (fifty-two percent, $n=74$ ). Non-London commercial firms were the most sceptical (only twenty-six percent, $n=6$ disagreed with the proposition) and

\footnotetext{
${ }^{43}$ Only 4\% ( $\left.\mathrm{n}=10\right)$ disagreed or strongly disagreed and $8 \%(\mathrm{n}=17)$ were ambivalent.
} 
high street and legal aid firms were the least sceptical (seventy-seven percent, $n=27$ and seventy-five percent, $n=9$ disagreed with the proposition). Interestingly however, high street and legal aid practice solicitors, along with West London commercial solicitors, most frequently agreed that pro bono is a public relations exercise for the firm (between fifty-three percent and forty-six percent).

Women were more likely to be of the view that pro bono work was often provided for existing clients rather than a separate client group, they also appeared to be more cynical that it is used as a public relations exercise by firms. On the other hand, this did not lead the male or the sceptical female respondents to feel, to any great degree, that pro bono clients were not given as good a service as other clients. ${ }^{44}$ Interestingly it was legal aid practitioners who were more inclined to feel that pro bono was provided for existing clients (forty-two percent, $\mathrm{n}=5)^{45}$ and City commercial practitioners who disagreed (fifty-five percent $\mathrm{n}=28$ ). However, pro bono work within their definitions must also have been provided to their fee-paying client base in many instances as well, when one considers the large percentages of work carried out in commercial areas of law. Solicitors in this sample from City commercial firms were very positive about the value of their firm's contribution to the local community at eighty-four percent $(n=43)$ agreement with the statement, as were legal aid practitioners (ninety-two percent, $n=11$ ) and high street solicitors (eighty-five percent, $\mathrm{n}=28$ ). Scepticism as to firms' motives for promoting pro bono did not lead young solicitors to conclude that clients or the wider community were being badly served by the services

\section{iii. Education and Training}

The questionnaire sought views on the educational and training needs of young solicitors carrying out pro bono work to establish how well equipped young solicitors felt to provide pro bono services and whether pro bono training was of importance to them. Three propositions were advanced in the questionnaire:

- I would like training in areas of law outside my main practice areas in order to serve my pro bono clients better.

- I would like to spend some of my training contract seconded to an organisation undertaking pro bono work, for example a law centre.

- Trainees should have the opportunity to choose subjects at law school which would be relevant to pro bono work even if not in areas normally practised by the firm.

There was some concern that solicitors were not well equipped at present to provide effective pro bono services. Forty percent $(n=59)$ of those who replied would like to have spent some of their training contract seconded to a pro bono organisation, and/or to carry out pro bono work for outside organisations. ${ }^{46}$ This was particularly true of

\footnotetext{
${ }^{44}$ There are question marks over the quality of the service that is provided to pro bono clients, albeit in general terms and in part as a function of the lack of a clear pro bono evaluation framework. See the section on Lack of Normative Standards, Pro bono in the 1990's: The Uncertain Future of Attorney Volunteerism., Esther F. Lardent, Pro bono Institute President, paper presented at the Conference on Access to Justice in the 1990's sponsored by the American Bar Association Consortium on Legal Services and the Public and Tulane Law School May 1989.

${ }^{45}$ Although these clients were presumably on low incomes who required social welfare advice.

46 The Lord Chancellors' Advisory Committee on Legal Education and Conduct First Report on Legal Education and Training (London: ACLEC 1996) at 85-97.
} 
local government and in-house solicitors, who provided no work pro bono at all. There was some interest, especially from trainees, in training in areas of law outside those in which they practised during office hours, to allow them to serve their pro bono clients better. This adds fuel to the case for more variety in professional and post qualification training.

Many of the young profession felt that their legal training at law school ought to provide them with the breadth of subjects to enable them to serve pro bono clients effectively. ${ }^{47}$ Whether they considered that they would only be marketable to City commercial firms if they selected commercial law options, or whether direct pressure was applied by careers advisers or firms themselves was unclear. Fifty-four percent $(n=115)$ of respondents either agreed or strongly agreed with the proposition that trainees should be able to choose subjects at law school that would be relevant to pro bono work, even if not in areas normally practised by the firm with whom they have a training contract. Disagreement or strong disagreement was limited to eighteen percent who were not in favour of broadening the law school options to students for pro bono reasons. However, trainees (fifty-eight percent, $n=64$ vs. twenty-seven percent, $n=19$ ), favoured this rather than qualified solicitors who were against it by a simple majority (fifty-two percent, $n=36$ ). One respondent even went so far as to express concern that a broader legal training would leave trainees unemployable.

iv. Individuals’ own experiences of pro bono work and/or future hopes

The questionnaire asked respondents to give their views on statements aimed at examining individuals' experiences of pro bono work and their views on future participation.

- I would like to do some or more pro bono work.

- I enjoy the pro bono work that I do.

- I feel that I am a more skilled lawyer as a result of my pro bono experience.

- The pro bono work that I do is given full and proper credit by my firm e.g. in time recording, appraisals.

Few respondents from any of the firms, whether trainees or qualified solicitors, whether male or female, were totally against carrying out some or more pro bono work. Local government, in-house and West London commercial solicitors were most keen to carry out more pro bono work (eighty percent $n=4$, eighty-six percent $n=6$, sixty-seven percent $n=6$ ) which were the groups with the lowest pro bono participation rates. Trainees were more in favour of doing some or more pro bono that their qualified counterparts (sixty-one percent, $n=76$ vs. forty-four percent, $n=39$ ).

Whilst the majority of solicitors stated that they had enjoyed the pro bono that they did (fifty-nine percent, $n=66$ ), and a large minority of them felt quite strongly that their participation had made them more skilled lawyers (forty-five percent, $n=52$ ), they were less positive about the recognition that they received for their pro bono work by their

\footnotetext{
${ }^{47}$ Voluntas, the pro bono organisation of the Victoria law Foundation, is actively lobbying for pro bono publico to be included in the law school curriculum and aims to promote professional development for those wishing to provide pro bono work. See Objectives and Strategies 1999/2000. (Melbourne, Australia, Voluntas, Victoria Law Foundation, 1999).
} 
firms. ${ }^{48}$ Few solicitors felt that the pro bono work that they carried out was given full and proper credit by the firm, indicating that it was not given credit and secondly that these respondents felt that it ought to be. Only ten percent $(n=12)$ were adamant that it was recognised fully by their firm and a further twenty-eight percent $(n=33)$ agreed that they were given some recognition. Just as many felt completely the opposite. Recognition appears to be an important issue for young solicitors, that is to say recognition by more senior members of the profession who are, in many cases, advocating their participation both within the firm and to policy makers. ${ }^{49}$

Recognition practices appeared to vary by firm type. City commercial firms were more likely to give "credit" for pro bono work in some way, either by having incentive schemes or by crediting pro bono hours worked towards billable hours targets. ${ }^{50}$ Fiftyone percent $(n=20)$ who worked for City firms felt that they were given full and proper credit, few felt that they were not given credit or given no credit at all for their pro bono activities (fifteen percent, $\mathrm{n}=6$ ). This ties in with the encouragement that City commercial firms appeared to give to their staff to carry out pro bono work, and the supervisory support that they also provided. The supervisory process may make them more aware of the amount of pro bono that is being carried out, or it may illustrate a more favourable attitude towards pro bono participation and their views on its merit.

Legal aid practitioners felt that some credit was given for their pro bono work, but not full credit (fifty percent, $n=6$ ), although they do not feel that their efforts were totally ignored. Once again, West London commercial and non London commercial firms did not feel that pro bono work was recognised, although it is unclear from this response whether they were talking generally about their firm's attitudes or whether they referred to pro bono work that they have carried out in the past. Lack of encouragement could explain why few solicitors from this type of firm carry out pro bono work, although this may be a perception by respondents of what their firm's attitudes would be, rather than a tried and tested assertion.

\section{Conclusion}

Pro bono legal work continues to attract column inches and spark debate both within the legal profession and without. It has come to public prominence through recent pronouncements by politicians, through media scrutiny of legal professionals' earnings and in discussions surrounding their role in making up the shortfall in legal service

\footnotetext{
${ }^{48}$ Almost two thirds of all law firms responding to the Law Firm Pro bono Project Survey (as mentioned above) in the United States claimed that they provided some form of recognition to attorneys in their firms for their pro bono work.

${ }^{49}$ This replicates Boon and Whyte's findings on the need for recognition by the solicitor's firm, supra n. 2 at 173.

${ }^{50}$ Once again, this accords with US large law firm findings whereby there is increasing recognition of pro bono work, to the extent that it is accorded equal status in terms of billable hours as full fee-paying work. See The Law Firm Pro bono Project Guide supra n.6 at 4. Also borne out by Boon and Whyte's findings that suggested that progressive commercial firms were providing pro bono leadership by senior staff supra n. 2 at 173.
} 
provision that cannot be met through Legal Aid or other initiatives. ${ }^{51}$ There is a long tradition that links pro bono work with the law, although the linkage between the two is less than clear. ${ }^{52}$ Some commentators, following Kant's philosophy, have explained the connection as hailing from issues of personal morality, of altruism not specific to the legal profession but universal to all. Others have grounded pro bono in a notion of public service which has been engendered into the legal profession who, as a result of status and learning, are able to assist others who are less fortunate. ${ }^{53}$ Some have wrapped pro bono within the veil of professionalism and professional ethics, a collective responsibility shared by the whole profession. ${ }^{54}$ As Goriely states:

"It is inherent to the notion of professionalism that the service provided is of universal importance - which suggests that even the poor may, on occasion, require legal services. To provide legal services for the poor is to assert the universality of the law. ${ }^{155}$

Others, particularly those who are allied to the pro bono movement and work with the profession to try to increase pro bono participation have sought to distance the debate from ethics or morality not least because expressions of duty have failed to quicken many legal professionals into action. Instead they have sought to convince the profession that pro bono is rooted in sound commercial principles. The rebranding of pro bono as an advertising tool or a method of reinvestment in the market is seen to be a better method by which to sell the idea to business-minded professionals. ${ }^{56}$ Still more seek the middle ground, a call to ethics coupled with the recognition that much legal work takes place within a business environment:

" A pro bono commitment should be every law firm's answer to corporate citizenship; the profession's collective response to a new political and social era with a heightened awareness of business ethics and a recognition that business goes beyond a limited bottom-line approach that benefits only shareholders or partners. ${ }^{\prime 57}$

\footnotetext{
51 "Hard Labour?" The Times 7 November 1995 at 35. This is not just a concern expressed by commentators on English pro bono and legal aid debates. The nexus between increasing pro bono and decreasing legal aid provision was also denied by the Attorney-General of Australia in his opening address "For the Public Good: The First National Pro bono Law Conference" $4^{\text {th }}$ August 2000, Canberra Australia. See also Lord Phillips of Sudbury's question to Her Majesty's Government " ... whether they [the Government] will take into account the pro bono activities of firms of solicitors in the private sector when selecting them for government work." The Lord Chancellor replied that the government, whilst following public purchasing criteria based on value for money, may consider pro bono work relevant in assessing the value and expertise that the firm may profess to have. Hansard HL2026 Written Answer $29^{\text {th }}$ April 1999. This is not just a concern expressed by commentators on English pro bono and legal aid debates. The nexus between increasing pro bono and decreasing legal aid provision was also denied by the Attorney-General of Australia in his opening address, ibid.

${ }^{52}$ For a discussion of the pro bono tradition and its roots see further Boon and Whyte, supra n.2.

${ }^{53}$ See further T. Goriely "Law for the Poor: The Relationship between Advice Agencies and Solicitors in the Development of Poverty Law" (1996) 3 International Journal of the Legal Profession 215.

${ }^{54}$ See further D. Luban, Lawyers and Justice: An Ethical Study (Princeton, NJ: Princeton University Press 1988). See also Esther F. Lardent, The Case Against: Just Say No ... To Mandatory Pro bono, the American Lawyer Pro bono Guide Issue (American Lawyer Media, 1996).

${ }^{55}$ T Goriely, supra n.52.

${ }^{56}$ See J. Scott, Corporations, Classes and Capitalism (London: Hutchinson, 1979).

${ }^{57}$ Peta Sweet, founding director of the Solicitors Pro bono Group "Doing Good to do Better" The Times March 282000.
} 
It is a debate that profoundly affects all levels of the profession and in particular those who are at the start of their careers. ${ }^{58}$ There is an opinion amongst some young solicitors that they are being required to take on the pro bono burden where their seniors have chosen not to. ${ }^{59}$ If the idea is to be sold to the young profession in the long term, it appears from the survey that the young solicitors will have to feel that it is of benefit, whether to others or themselves. Some stated that they were motivated by the desire to provide a service to the community in the tradition of pro bono legal work. Others appear to respond to the opportunity of personal or career development, whether this is through increased client contact or exposure to different types of legal situations, some by both.

All levels of the young profession considered that a commitment to pro bono would improve the profession's image, even though those approaching senior status are more likely to consider pro bono to be a public relations exercise rather than a duty. Seniority appears to diminish the view that pro bono is part of a solicitor's professional and ethical obligations. This does not, however, extinguish an acceptance of the merit of pro bono to the community. Whilst many were convinced that the service that pro bono clients received was of a good standard, others were more sceptical and some very critical. And yet young solicitors are concerned about their ability to carry out the work, to spend sufficient time on cases for pro bono client and, understandably also, that they will progress in their careers. Where these expectations have not been met, participation levels have dropped. It appears that young solicitor's pro bono participation will only be increased if firms are willing to view pro bono as a partnership between themselves and their staff, if they allow them the time, provide them with supervisory support and offer sufficient recognition for their efforts. Some firms have given their commitment already, others show reluctance even to their staffs' own commitment outside office hours. Further training, a degree of flexibility in the provision of pro bono services and a good deal of encouragement will be needed if the more experienced young solicitors are to be encouraged to continue working pro bono. The more pertinent question for the solicitor's profession, therefore, now appears to be not whether the young profession is interested in undertaking pro bono services, but whether the profession as a whole is sufficiently motivated to provide active and firmbased support to match their young solicitors' willingness.

\footnotetext{
${ }^{58}$ Law students are being heralded as the new pro bono activists with programmes such as the College of Law's free advice centre attracting substantial numbers of legal practice course students. This service is, however, billed as a legal education tool that has the benefit of providing a service to the public, rather than a pro bono service that also serves a educational need. See also Danny Lee, “'Mean' Lawyers Not Guilty", The Guardian April 6 $6^{\text {th }} 1999$.

${ }^{59}$ This view was expressed as part of the TSG/YSG study discussed in more detail below. Indeed pro bono is being sold as a way of introducing young solicitors to their ethical professional responsibilities, whilst side-stepping the question as to whether those in more senior positions should be required to live up to those professional standards in equal measure. See, for example, the Attorney-General of Australia's opening address to the First National Pro bono Law Conference, supra n.50, in which he states "16. Pro bono work is also integral to the legal profession - not only as a demonstration of its commitment to the community but also as a means of nurturing a sense of social and professional responsibility in young lawyers." $4^{\text {th }}$ August 2000, Australia.
} 